\title{
Significance of dermal and respiratory uptake in creosote workers: exposure to polycyclic aromatic hydrocarbons and urinary excretion of 1-hydroxypyrene
}

\author{
Eivor Elovaara, Pirjo Heikkilä, Lauri Pyy, Pertti Mutanen, Vesa Riihimäki
}

\begin{abstract}
Objectives-To evaluate workers' exposure in a creosote impregnation plant by means of ambient and biological monitoring.

Methods-Naphthalene (vapour phase) and 10 large molecular polycyclic aromatic hydrocarbons (PAHs) (particulate phase) were measured in the breathing zone air during an entire working week. 1-Hydroxypyrene (1-HP) was measured in 24 hour urine as a metabolite of the pyrene found in neat (dermal exposure) and airborne creosote.
\end{abstract}

Results-Naphthalene (0.4-4.2 $\left.\mathrm{mg} / \mathrm{m}^{3}\right)$ showed 1000 times higher concentrations in air than did the particulate PAHs. In total, the geometric mean (range) of three to six ring PAHs was $4.8(1 \cdot 2-13 \cdot 7)$ $\mu \mathrm{g} / \mathrm{m}^{3}$; pyrene $0.86(0.23-2 \cdot 1) \mu \mathrm{g} / \mathrm{m}^{3}$, and benzo(a)pyrene $0.012(0.01-0.05) \mu \mathrm{g} / \mathrm{m}^{3}$. There was no correlation between pyrene and gaseous naphthalene. The correlations between pyrene and the other nine particulate PAHs were strong, and gave a PAH profile that was similar in all air samples: $r=0.83$ (three to six ring PAHs); $r=0.81$ (three ring PAHs); $r=$ 0.78 (four to six ring PAHs). Dermal exposure was probably very high in all workers, because the daily output of urinary 1-HP exceeded the daily uptake of inhaled pyrene by $\leqslant 50$-fold. Urinary 1 HP concentrations were very high, even on Monday mornings, when they were at their lowest (4-22 $\mu \mathrm{mol} / \mathrm{mol}$ creatinine). 1-HP seldom showed any net increase over a workshift (except on Monday) due to its high concentrations (16 to 120 $\mu \mathrm{mol} / \mathrm{mol}$ creatinine) in the morning samples. 1-HP was always lower at the end of the shift (19 to $85 \mu \mathrm{mol} / \mathrm{mol}$ creatinine) than in the evening (27 to 122), and the mean (SD) change over the working week (47 (18)) was greater than the change over Monday (35 (32)). The timing of 1-HP sampling is therefore very important.

Conclusions-Urinary 1-HP proved to be a good biomarker of exposure to three to six ring PAHs but not to airborne naphthalene. Hence, biomonitoring based on 1-HP has to be completed with exposure assessment for naphthalene as a marker for creosote volatiles that mainly enter the body through the lungs.

(Occup Environ Med 1995;52:196-203)
Keywords: occupational exposure; naphthalene; pyrene; benzo(a)pyrene; biological monitoring

Creosote oil is a wood preservative derived from coal tar. Occupational exposure, which may take place by inhalation of its vapour as well as aerosol fractions, or through skin contact, is a recognised health hazard. It causes mainly toxic effects to the skin and eyes ${ }^{12}$ and is probably carcinogenic to humans. ${ }^{3}$ More than 100 different compounds have been analysed in creosote oils, and it has remained unclear which specific chemicals are primarily accountable for the harmful effects. ${ }^{24}$ Analysis of polycyclic aromatic hydrocarbons (PAHs) in Finnish creosote impregnation plants ${ }^{5}$ has shown that naphthalene and its alkyl derivatives $\left(0 \cdot 1-11 \mathrm{mg} / \mathrm{m}^{3}\right)$ were the main volatiles in the air, with concentrations 1000 times higher than the particulate PAHs (0.2-46 $\mu \mathrm{g} / \mathrm{m}^{3}$ ). Pyrene was a major constituent of the large molecular PAHs (four to six rings) of both the neat and airborne creosote.

Complex chemical exposures are a health concern whenever they involve PAHs, a class of compounds considered to have human carcinogenic potential. ${ }^{16}$ Workers in industrial operations with high airborne concentrations of PAHs show, in particular, excess rates of lung cancer, ${ }^{7-10}$ and workers exposed specifically to creosote have an excess of lip and skin cancer. ${ }^{11}$ The measurement of 1-hydroxypyrene $(1-\mathrm{HP})$ in urine is a method used to monitor exposure not only to its parent compound pyrene, ${ }^{1213}$ but also as a biomarker for total exposure to PAHs, both of occupational $^{14-19}$ and other origins. ${ }^{150-22}$ The assay for 1-HP offers a method to assess the absorption of pyrene or PAHs by all routes of entry. The importance of the dermal absorption is increasingly considered in studies on occupational exposure to PAHs. ${ }^{23}{ }^{24}$ In creosote workers, the skin is probably the most important route of exposure to PAHs. ${ }^{25}$

This study was conducted outdoors in a creosote impregnation plant. The purpose was to assess: (a) the workers' exposure through inhaled air by measuring naphthalene, pyrene, benzo(a)pyrene, and eight other PAHs in the breathing zone from whole shift air samples over five days, and $(b)$ the workers' internal exposure with the aid of the urinary 1-HP method. The study focused on different exposure routes (dermal and inhalatory), the variations in individual exposures, and the optimal urine sampling time for 1-HP measurement in an occupational biomonitoring scheme. 


\section{Materials and methods}

CHEMICALS

The PAHs used for standardisation were: naphthalene and anthracene (Merck, Darmstadt); fluorene (Merck-Schuchardt, Hohenbrunn bei Munchen); phenanthrene, pyrene, benzo(a)pyrene, and fluoranthene (Fluka, Buchs); benzo(a)fluorene, chrysene, benzo(e)pyrene, dibenzo(ah)anthracene, and benzo(ghi)perylene (Ega-Chemie, Steinheim); and benzo(k)fluoranthene (Community Bureau of Reference, Commission of European Communities, Brussels). The purity was $>97 \%$ for all PAH standards. 1-Hydroxypyrene was from Janssen Chimica, 2340 Beerse, Belgium. $\beta$-Glucuronidase and arylsulphatase $(100000$ Fishman $\mathrm{U} / \mathrm{ml}$ and 800000 Roy U/ml) were from Boehringer, Mannheim, Germany. The purity of the solvent chemicals was of high performance liquid chromatography (HPLC) grade.

\section{SUBJECTS AND STUDY DESIGN}

The measurements were carried out in an impregnation plant, where railway ties (sleepers) were impregnated with creosote (imported from Poland). Six men with different jobs volunteered to participate in this study. The five day air sampling period was preceded and followed by a work free period of 64 hours. All workers wore leather protective gloves and cotton overalls, but no one used a respiratory protector. Employees Nos 2 and 3 worked overtime (until $630 \mathrm{pm}$ ) on Monday, which was an exception from the regular eight hours a day schedule (fig 1 ).

\section{AIR SAMPLING AND PAH ANALYSES}

Personal breathing zone air samples were taken on five consecutive days in July 1987. Particulate PAHs (air sample volume 200-700 1) were collected during the whole shift (600 am to $200 \mathrm{pm}$ ) in one or two periods on prewashed $37 \mathrm{~mm}$ filters (Glassfibre Prefilter SM 13400, Sartorius AG, Goettingen, Germany) at a flow rate of $21 /$ min (suction velocity $3.5 \mathrm{~cm} / \mathrm{s}$ ), whereafter the filters were wrapped in aluminium foil, stored in a
Figure 1 Concentrations of 1-HP in urine and the pyrene in breathing zone air of six workers in a creosote impregnation plant. All points of 1-HP analysis that represent complete and successive urine voids are linked by a line (all participants did not succeed in providing complete sets of samples).
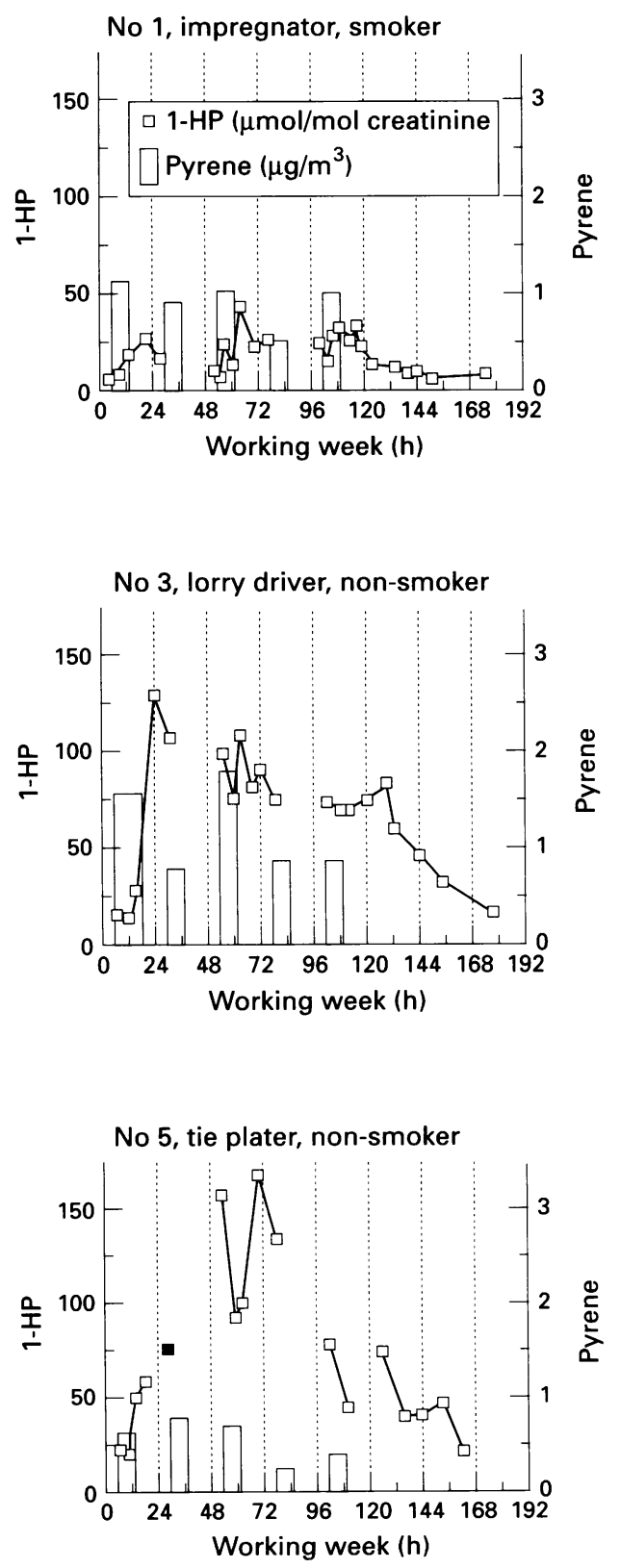

No 2, assistant operator, non-smoker
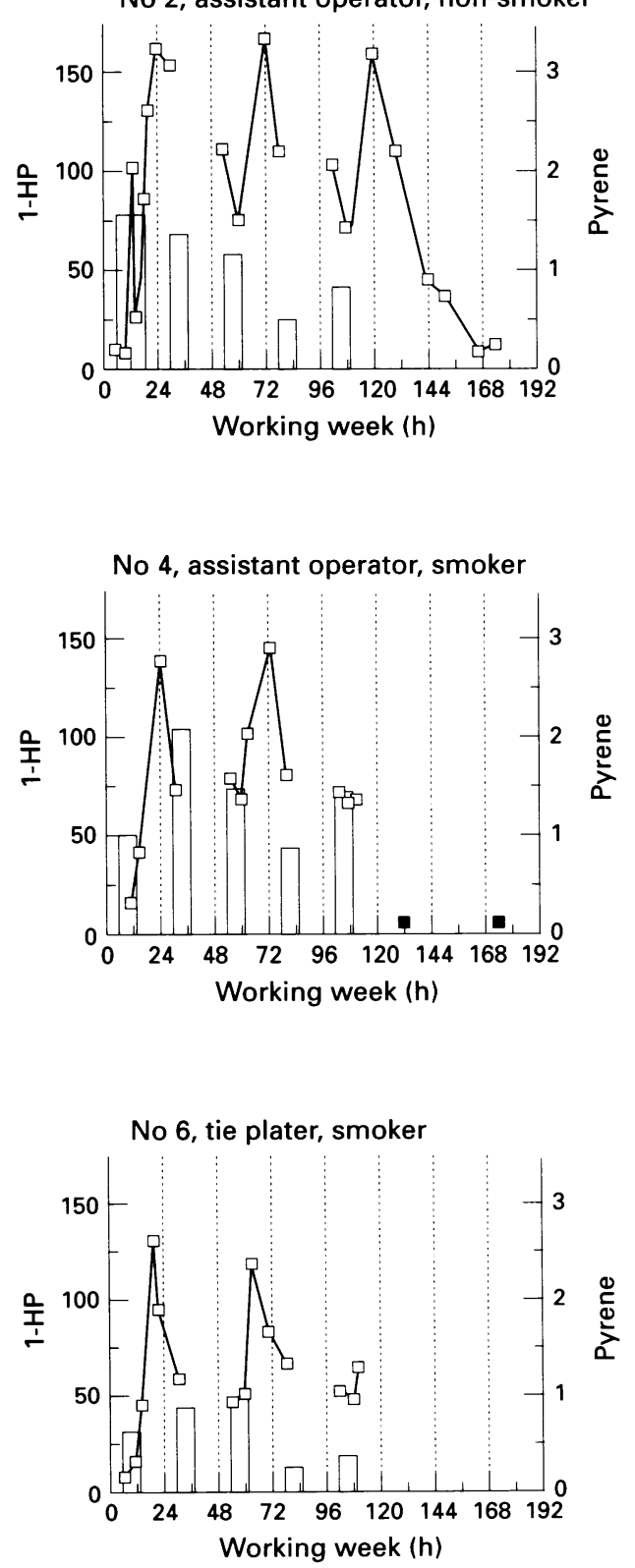
refrigerator, and analysed within seven weeks. The samples were extracted into cyclohexane $(60 \mathrm{ml})$ by a Soxhlet system for eight hours, evaporated to dryness under $\mathrm{N}_{2}$ flow at room temperature, redissolved in $1 \mathrm{ml}$ of $85 \%$ acetonitrile aqueous solution by ultrasonication for four minutes and analysed for PAHs in a single chromatographic run with reversed phase HPLC with fluorescence detection (Perkin Elmer Series 4/Perkin Elmer LS4) with an octadecylsilyl P-E HS-3, RP18 (100 $\times 4.6 \mathrm{~mm})$ column, a Perisorb RP-18 $(30 \times$ $2 \cdot 1 \mathrm{~mm}$ ) precolumn, and with a linear gradient program from $65 \%$ to $85 \%$ of acetonitrile in water $(1 \% / \mathrm{min})$. Measurement was based on peak heights with pure PAH standards (in acetonitrile). The detection limit for benzo(a)pyrene was $5 \mathrm{pg}$ (injection volume 6 $\mu \mathrm{l}$ ), which corresponds to an air concentration of about $8 \mathrm{ng} / \mathrm{m}^{3}$ in an air sample of 1001 .

In the gaseous phase, naphthalene ( $>99 \%$ of its total air concentration) was the only PAH collected (parallel to the filter samples) on XAD-2 resin tubes (yield $88(9 \%)$ ) and assayed as described by Heikkilä et al. ${ }^{5}$

\section{BIOLOGICAL MONITORING}

The workers were asked to collect all urine passed within the 24 hour period into divided samples for the designated periods. Specimens collected at home and at work were stored in the refrigerator until transferred to a deepfreeze $\left(-20^{\circ} \mathrm{C}\right)$.

\section{DETERMINATION OF URINARY 1-HP}

The method of Jongeneelen and coworkers ${ }^{13}$ was used to analyse 1-HP in urine. Thawed urine $(5 \mathrm{ml}$ samples, stored for one year at $-20^{\circ} \mathrm{C}$ without preservatives) was adjusted to pH 5.0 with $1 \mathrm{~N} \mathrm{HCl}$. Sodium acetate buffer ( $5 \mathrm{ml}$ of $0.2 \mathrm{M}, \mathrm{pH} 5.0$ ) containing $12.5 \mu \mathrm{l}$ of $\beta$-glucuronidase and arylsulphatase was added for enzymatic hydrolysis (complete) at $37^{\circ} \mathrm{C}$ for three hours. Mega Bond Elut C-18 cartridges (from Analytichem International, USA) were used for solid phase sample clean up: after priming ( $5 \mathrm{ml}$ methanol, $10 \mathrm{ml}$ $\mathrm{H}_{2} \mathrm{O}$ ), the hydrolysed sample was loaded, washed $\left(10 \mathrm{ml} \mathrm{H}_{2} \mathrm{O}\right.$, then $10 \mathrm{ml} 20 \%$ acetonitrile), and the retained $1-\mathrm{HP}$ was eluted in $10 \mathrm{ml}$ of methanol. If needed, the eluate was concentrated 10 -fold to 20 -fold by evaporation (under $\mathrm{N}_{2}$ flow) and redissolved in methanol. The sample tubes were protected from light with aluminium foil. Standards of 1-HP were prepared in pooled blank urine $(0,10,100,250,500,750,1000$ $\mathrm{nmol} / \mathrm{l}$ ) and carried through the analytical procedures. The 1-HP was analysed with a Shimadzu HPLC system: a manual sample injector (20 $\mu \mathrm{l}$ loop), a ChromSep column $(100 \times 3 \mathrm{~mm}$ ID packed with ChromSpher PAH, Chrompack, Middelburg, Netherlands), and a fluorescence detector (from $\lambda 242 \mathrm{~nm}$ to $\lambda 388 \mathrm{~nm}$ ) were used with acetonitrile-tetrahydrofuran-water $\quad$ (37:5:58 by volume) as the mobile phase of isocratic runs (fig 2). Quantification was based on peak area counts. The coefficient of variation was $4 \%$ (for pooled urine with 1 -HP $1 \mu \mathrm{mol} / 1$ $\mathrm{n}=9$ ) and the recovery of added standards in urine was $65 \%$. Urinary creatinine was determined $^{26}$ to correct for urine dilution and to express the 1-HP excretion per mol creatinine.

\section{STATISTICAL ANALYSIS}

The normality of the distribution of the air analysis data of the original and the log transformed PAH variables was checked. A nonparametric method (Spearman) was used for correlation analysis, because some of the transformed variables (log pyrene, $P=0.068$; $\log$ of the sum of four to six ring PAHs, $\mathrm{P}=$ 0.011 ) were not normal.

\section{Results}

Naphthalene was determined in the vapour phase (XAD tube analysis) whereas pyrene and nine other larger PAHs were determined in the particulate phase (filter analysis) of the breathing zone air of six workers during a working week. Table 1 shows the PAHs in creosote oil (dermal exposure) and in whole shift air (eight hour time weighted average (TWA)). The geometric mean (range) air concentration of total particulate PAHs

Table 1 Studied PAHs in creosote oil ${ }^{\star}$ and in workers' breathing zone air

\begin{tabular}{|c|c|c|c|c|c|}
\hline \multirow[b]{2}{*}{$P A H$} & \multirow[b]{2}{*}{$\begin{array}{l}\text { Aromatic } \\
\text { rings }\end{array}$} & \multirow{2}{*}{$\begin{array}{l}\text { Concentration } \\
\text { in creosote } \\
\text { ( } \mu \mathrm{g} / \mathrm{mg})\end{array}$} & \multicolumn{3}{|c|}{ Daily $8 h T W A P A H$ concentration in air $\left(\mu g / m^{3}\right)$} \\
\hline & & & $\begin{array}{l}\text { Arithmetic } \\
\text { mean (SD) }\end{array}$ & $\begin{array}{l}\text { Geometric } \\
\text { mean }(S D)\end{array}$ & Range \\
\hline Naphthalene & 2 & 97 & $1536(1036)$ & $1254(1.91)$ & $370-4200$ \\
\hline Phenanthrene† & 3 & 35 & $4.02(2.56)$ & $3.25(2.01)$ & $0 \cdot 78-10 \cdot 0$ \\
\hline Fluorenet & 3 & 44 & $0.30(0.35)$ & $0.19(2.52)$ & $0.04-1.53$ \\
\hline Pyrenet & 4 & 1.9 & $0.97(0.45)$ & $0.86(1.69)$ & $0 \cdot 23-2 \cdot 10$ \\
\hline Chrysenet & 4 & $0 \cdot 15$ & $0 \cdot 17(0.10)$ & $0.14(1.73)$ & $0.05-0.47$ \\
\hline Benzo(a)fluorenet & 4 & 0.25 & $0.094(0.084)$ & $0.068(1.84)$ & $0.02-0.40$ \\
\hline Benzo(e)pyrenet & 5 & $0 \cdot 2$ & $0.047(0.044)$ & $0.036(2.06)$ & $0.01-0.21$ \\
\hline Benzo(k)fluoranthene $\ddagger$ & 5 & NA & $0.014(0.010)$ & $0.014(2.51)$ & $0.01-0.055$ \\
\hline Benzo(a)pyrenedा & 5 & 0.05 & $0.014(0.010)$ & $0.012(1.57)$ & $0.01-0.050$ \\
\hline Dibenzo(ah)anthracenef & 5 & 0.06 & $0.011(0.002)$ & $0.010(1 \cdot 16)$ & $0.01-0.020$ \\
\hline Benzo(ghi)perylenef & 6 & 0.09 & $0.012(0.004)$ & $0.011(1.28)$ & $0.01-0.025$ \\
\hline Total PAHs excluding naphthalene & & $81 \cdot 7$ & $5 \cdot 70(3 \cdot 36)$ & $4.77(1.88)$ & $1 \cdot 23-13 \cdot 74$ \\
\hline \multirow{2}{*}{$\begin{array}{l}\text { Ratios in creosote oil and in air: } \\
\text { Naphthalene/total 3-6 ring PAHs }\end{array}$} & & & & & \\
\hline & & $1 \cdot 2$ & $333(281)$ & $266(1.9)$ & $69-1556$ \\
\hline
\end{tabular}

Results represent air sampling of five days and six men $(n=30)$. NA = not analysed. ${ }^{\star}$ Data from a previous publication $($ Nylund, et al 1992). ${ }^{4}$ According to the overall evaluation of carcinogenicity to humans as classified by IARC (1987). +Carcinogenicity not et al 1992). ${ }^{4}$ According to the overall evaluation of carcinogenicity to humans as classified by IARC (1987). TCarcinogenicity not
classifiable (group 3); fpossibly carcinogenic (group 2B); fonly for this PAH there is an occupational limit value $\left(10 \mu \mathrm{g} / \mathrm{m}^{3}, 8 \mathrm{~h}\right.$ classifiable (group 3 ); †possibly carcinogenic (group 2B);
TWA) in Finland ${ }^{31}$; (probably carcinogenic (group 2A). 
Table 2 Correlation analysis between pyrene and the other PAHs in creosote workers' breathing zone air

\begin{tabular}{|c|c|c|c|c|c|c|c|c|}
\hline $\begin{array}{l}\text { Worker } \\
\text { No }\end{array}$ & $\begin{array}{l}\text { Pyrene } \\
\left(\mu g / m^{3}\right)\end{array}$ & $\begin{array}{l}\text { 4-6 ring } \\
P A H s^{*} \\
\left(\mu g / m^{3}\right)\end{array}$ & $r$ & $\begin{array}{l}3 \text { ring } \\
\text { PAHst } \\
\left(\mu g / m^{3}\right)\end{array}$ & $r$ & $\begin{array}{l}\text { Naphthalene } \\
(2 \text { rings) } \\
\left(\mu \mathrm{g} / \mathrm{m}^{3}\right)\end{array}$ & $r$ & $\begin{array}{l}\text { Ratio in air: } \\
\text { Naphthalenel } \\
3-6 \text { ring PAHs }\end{array}$ \\
\hline $\begin{array}{l}1 \\
2 \\
3 \\
4 \\
5 \\
6 \\
\text { All workers }\end{array}$ & $\begin{array}{l}0.95(0.22) \\
1.12(0.43) \\
1.33(0.56) \\
1.37(0.49) \\
0.54(0.21) \\
0.66(0.40) \\
0.99(0.50)\end{array}$ & $\begin{array}{l}0.26(0.06) \\
0.31(0.13) \\
0.61(0.35) \\
0.43(0.21) \\
0.21(0.06) \\
0.24(0.09) \\
0.34(0.22)\end{array}$ & $\begin{array}{l}(0.96) \\
(0.53) \\
(0.97) \\
(0.71) \\
(0.97) \\
(0.80) \\
(0.78)\end{array}$ & $\begin{array}{l}2.69(1.57) \\
5.96(2.73) \\
4.88(1.95) \\
8.27(5.02) \\
2.58(1.34) \\
3.58(3.28) \\
4.66(3.43)\end{array}$ & $\begin{array}{l}(0.63) \\
(0.73) \\
(0.49) \\
(0.87) \\
(0.76) \\
(0.98) \\
(0.81)\end{array}$ & $\begin{array}{c}560(190) \\
2140(1040) \\
1020(370) \\
2890(1110) \\
900(300) \\
1290(550) \\
1460(1040)\end{array}$ & 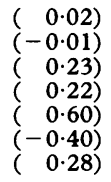 & $\begin{array}{l}188(123) \\
352(217) \\
177(111) \\
372(241) \\
338(188) \\
570(629)\end{array}$ \\
\hline
\end{tabular}

Values are arithmetic mean (SD) $(n=48) ; r=$ Spearman correlation coefficient; ${ }^{\star}$ The sum of chrysene + bentzo(a)fluorene + bentzo(e)pyrene + bentzo(k)fluoranthene + bentzo(a)pyrene + bentzo(ghi)perylene + dibentzo(ah)anthracene; the sum of phenanthrene + fluorene.
phente

(including pyrene) was $4 \cdot 77(1 \cdot 2$ to $13 \cdot 7)$ $\mu \mathrm{g} / \mathrm{m}^{3}(\mathrm{n}=30)$ and that of naphthalene was $1254(370-4200) \mu \mathrm{g} / \mathrm{m}^{3}(\mathrm{n}=30)$. In inspired air naphthalene had on average a 266 times higher concentration than the particulate PAHs. This contrasts (table 1) with their contents in creosote oils, where they occur in about equal amounts. ${ }^{4}$

The actual relations between pyrene and other PAHs in breathing zone air were evaluated from the air analysis data that represent altogether 48 sampling periods during the five day working week (table 2). The particulate PAHs, subgrouped for correlation analysis by molecular size, were compared with the pyrene concentration of the same sample. The correlation coefficients between pyrene and the three ring PAHs $(r=0.81)$, the four to six ring PAHs $(r=0.83)$, and the sum of the nine other particulate PAHs $(r=0.78)$ indicated that the PAH profile of all samples was very similar. As concentrations of the five to six
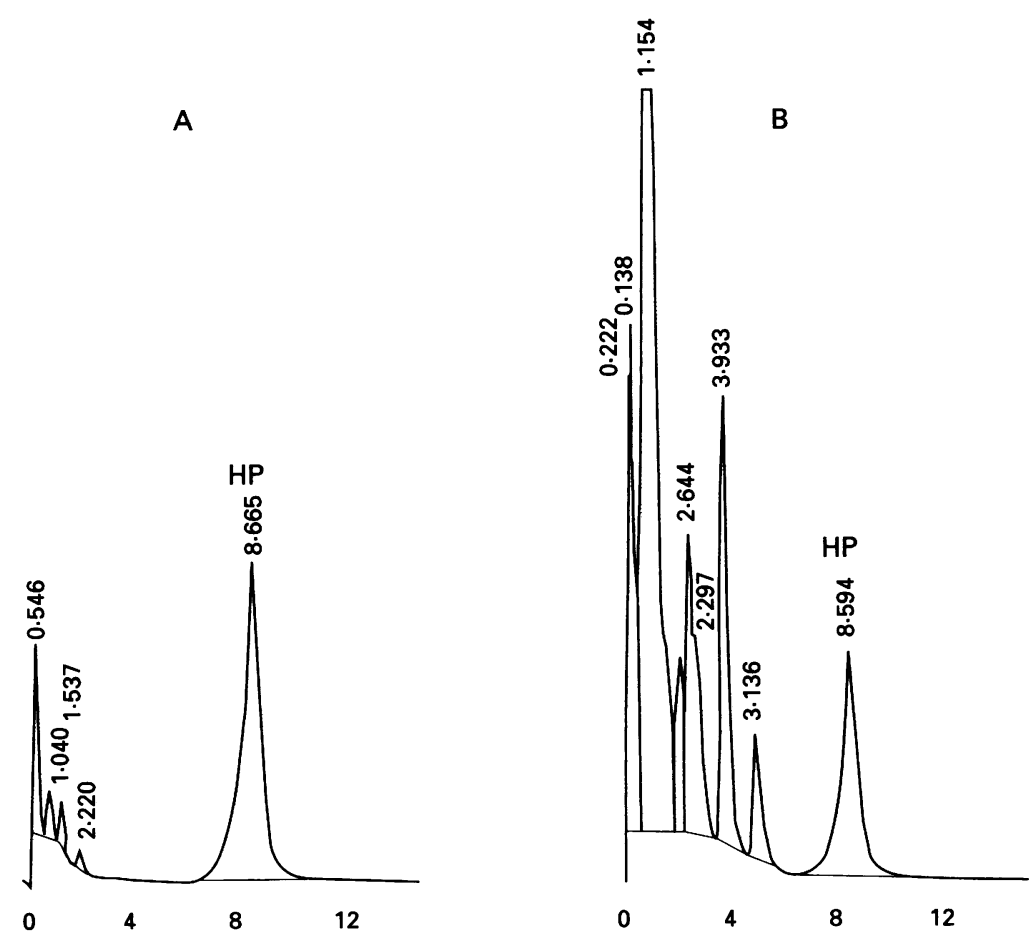

Figure 2 HPLC profiles of extracts from $(A)$ a pooled blank urine with a known amoun of the standard added to contain $1 \mu \mathrm{mol} / \mathrm{l}$ of 1-hydroxypyrene $(H P)$, and $(B)$ a pooled urine sample from workers exposed to creosote. ring PAHs were mostly near or below the limits of detection, no separate values were calculated for these. The best correlation $(r=0.86)$ was found between pyrene and the other four ring PAHs (chrysene + bentzo(a)fluorene, $\left.0.25(0.16) \mu \mathrm{g} / \mathrm{m}^{3}\right)$. The naphthalene concentrations varied greatly in relation to the particulate PAHs. For example, they were 250 to 5000 times higher than the concomitant concentrations of pyrene. It is thus evident that the air profiles of gaseous naphthalene, and the pyrene bound to air particulates, were not similar. Variation between workers was considerable and higher for naphthalene than for the other PAHs in air.

Figure 1 and tables 3 and 4 show the concentrations of 1-HP in urine and of pyrene in the daily inhaled air of the Monday to Monday follow up. Excretion of 1-HP showed greater variation between workers $(5 \cdot 5$-fold) than did inspirable pyrene $(2 \cdot 6$-fold) or the sum of nine other particulate PAHs (3.2fold). Workers Nos 1 and 2 exemplify extreme differences in 1-HP excretion, although the inspirable concentrations of pyrene showed no notable differences except on Monday, due to the overtime done by worker No 2 . The total exposure to airborne PAHs of worker No 2 seemed, however, to be higher than that of worker No 1 as judged from the overall ambient monitoring. Net increases in 1-HP over various time periods (table 3 ) suggested that the total exposure to pyrene was lowest in worker No 1 and highest in No 2 Worker No 5, whose breathing zone samples showed the lowest concentrations of inspirable pyrene, excreted 1-HP in urine at amounts almost as high as worker No 2 . The smoking habits of the workers did not seem to explain the differences in 1-HP excretion, whereas differences in creosote contamination, visible on the workers' skin, gloves, and overalls, seemed to be reflected by the daily 1-HP excretion (table 4). Skin exposure was most apparent for the jobs of assistant operators and tie platers who were transporting and actually handling the impregnated wood, whereas the impregnator clearly had the cleanest hands and clothes of all the workers.

In all creosote workers, the lowest concentrations of 1-HP were found in the Monday morning urine samples after 64 hours off work. The highest concentrations were consistently found in the evening samples (six to nine hours after the work) but never at the 
Table 3 Summary of the results from ambient and biological exposure monitoring of creosote workers

\begin{tabular}{|c|c|c|c|c|c|c|c|c|c|}
\hline \multirow[b]{3}{*}{$\begin{array}{l}\text { Worker } \\
\text { No }\end{array}$} & \multirow[b]{3}{*}{$\begin{array}{l}\text { Pyrene } \\
\text { in air } \\
\left(\mu g / m^{3}\right)\end{array}$} & \multirow{2}{*}{\multicolumn{5}{|c|}{ 1-HP in urine ( $\mu \mathrm{mol} / \mathrm{mol}$ creatinine $)$}} & \multicolumn{3}{|c|}{ Increase in 1-HP ( $\mu$ mol/mol creatinine $)$} \\
\hline & & & & & & & \multirow[b]{2}{*}{$\begin{array}{l}\text { Change; } \\
\text { working } \\
\text { day } \\
\text { Monday }\end{array}$} & \multirow[b]{2}{*}{$\begin{array}{l}\text { Change; } \\
\text { working } \\
\text { week }\end{array}$} & \multirow{2}{*}{$\begin{array}{l}\text { Change, } \\
\text { before } \\
\text { shifts: } \\
\text { Friday } \\
\text { minus } \\
\text { Monday }\end{array}$} \\
\hline & & $\begin{array}{l}\text { Monday } \\
\text { morning } \\
\text { before } \\
\text { work }\end{array}$ & $\begin{array}{l}\text { Tuesday } \\
\text { morning to } \\
\text { Saturday } \\
\text { morning }\end{array}$ & $\begin{array}{l}\text { End of } \\
\text { shiftt }\end{array}$ & $\begin{array}{l}\text { Evening } \\
\text { (after } \\
\text { work)t }\end{array}$ & $\begin{array}{l}\text { Weekend } \\
\text { (morning) } \ddagger\end{array}$ & & & \\
\hline $\begin{array}{l}1 \\
2 \\
3 \\
4 \\
5 \\
6 \\
\text { All workers }\end{array}$ & $\begin{array}{l}0.90(0.24) \\
1.09(0.39) \\
1.25(0.44) \\
1.39(0.49) \\
0.53(0.22) \\
0.65(0.31) \\
0.97(0.45)\end{array}$ & $\begin{array}{r}4 \\
9 \\
16 \\
17 \\
22 \\
9 \\
13(7)\end{array}$ & $\begin{aligned} 16(7) \\
120(20) \\
89(16) \\
77(9) \\
104(40) \\
58(10) \\
77(37)\end{aligned}$ & $\begin{array}{l}19(10) \\
85(18) \\
70(25) \\
71(31) \\
64(20) \\
79(29) \\
64(23)\end{array}$ & $\begin{array}{r}27(8) \\
122(63) \\
95(25) \\
119(50) \\
113(78) \\
105(60) \\
97(35)\end{array}$ & $\begin{aligned} & 12 \rightarrow 4 \rightarrow 7 \\
& 115 \rightarrow 38 \rightarrow 13 \\
& 85 \rightarrow 34 \rightarrow 18 \\
& 6 \rightarrow \mathrm{ND} \rightarrow 6 \\
& 74 \rightarrow 47 \rightarrow \text { ND } \\
& \text { ND }\end{aligned}$ & $\begin{array}{l}12 \\
96 \\
10 \\
24 \\
28 \\
38 \\
35(32)\end{array}$ & $\begin{array}{l}26 \\
63 \\
56 \\
53 \\
23 \\
59 \\
47(18)\end{array}$ & $\begin{array}{l}18 \\
96 \\
58 \\
56 \\
56 \\
50 \\
56(25)\end{array}$ \\
\hline
\end{tabular}

Values are the mean (SD); ${ }^{\star}$ whole shift TWAs of five days; $\mathrm{tn}=$ three days, Monday, Wednesday and Friday; $¥$ Saturday, Sunday and Monday; $§$ difference between urine specimens, Monday end of shift $(200 \mathrm{pm})$ minus Monday morning; qdifference between urine specimens, Friday end of shift minus Monday morning; $\mathrm{ND}=$ not determined.

end of the shift. In the morning samples of Tuesday to Saturday (after 16 hours off), the urinary 1-HP was often higher than in the middle or at the end of the shift. It was thus characteristic for 1-HP that it never reached peak excretion during the shift, a phenomenon more or less explained by the apparent dermal absorption continuing even after working hours. The net increases in individual 1-HP urine concentrations were calculated over (a) one working day (Monday), (b) one working week (Monday morning $\rightarrow$ Friday end of shift), and (c) before shifts (Monday $\rightarrow$ Friday).

To compare, on a molar basis, the pyrene inhaled over a working day with the 1-HP excreted in urine (table 4), the respiratory pyrene dose per working day was calculated by taking into account the uptake of both particulate and gaseous pyrene (the concentration of the gaseous pyrene is known to be maximally about $50 \%$ of the total pyrene 2425 :

$$
\text { Pyrene dose }=\mathrm{C}_{\text {total }} \times \mathrm{V} \times \mathrm{T} \times \mathrm{R}
$$

where $\mathrm{C}_{\text {total }}=2 \times \mathrm{C}_{\text {particulate }}$ pyrene concentration in air $\left(\mu \mathrm{g} / \mathrm{m}^{3}\right), \mathrm{V}=25 \mathrm{l} / \mathrm{min}$ ventilation rate (assumed), $\mathbf{T}=$ daily exposure time, $\mathbf{R}=$ $50 \%$ retention (assumed). Moreover, urinary excretion of 1-HP (as $\mu \mathrm{mol} / \mathrm{mol}$ creatinine at different times or $\mathrm{nmol} / 24 \mathrm{~h}$ ) did not show any significant correlation with the concentration of pyrene in the breathing zone air. As some of the workers apparently did not provide

Table 4 Crude approximation of daily pyrene uptake through dermal or inhalatory routes in six creosote workers

\begin{tabular}{llllll}
\hline Worker & Smoking & $\begin{array}{l}\text { Visible } \\
\text { contamination } \\
\text { on clothing }\end{array}$ & $\begin{array}{l}\text { Pyrene uptake } \\
\text { through } \\
\text { inhalation } \\
\text { (nmol/day) }\end{array}$ & $\begin{array}{l}\text { 1-HP in } \\
24 \text { h urine† } \\
\text { (nmol/day) }\end{array}$ & $\begin{array}{l}\text { Molar ratio: } \\
1-H P \text { in } 24 \text { h urinel } \\
\text { pyrene uptake } \\
\text { through inhalation }\end{array}$ \\
\hline 1 & + & Very low & $58(3)$ & $281(40)$ & $5(1)$ \\
2 & - & High & $77(35)$ & $1551(727)$ & $22(11)$ \\
3 & - & Low & $91(37)$ & $630(150)$ & $8(3)$ \\
4 & + & Moderate & $69(20)$ & $728(16)$ & $11(1)$ \\
5 & - & High & $30(9)$ & $1038(790)$ & $32(17)$ \\
6 & + & High & $46(16)$ & $576(31)$ & $13(4)$ \\
\hline
\end{tabular}

Values are mean (SD) of three workdays (Monday, Wednesday, and Friday; ${ }^{\star}$ See the text for the calculations based on pyrene concentrations measured in worker's breathing zone air (no correction was made for the pyrene uptake in tobacco smoke). †Indicative of total pyrene metabolism in the body, of which smoking may account at most for $20 \mathrm{nmol} / 24 \mathrm{~h}$ urine (Jongeneelen et al $\left.1990^{16}\right)$. complete 24 hour urine samples on all the experimental days, we rejected uncertain data. Then, of all the possible correlations calculated by linear regression analysis, the best one was shown between daily pyrene uptake (through inhalation) and the amount of 1-HP in 24 hour urine: $r=0 \cdot 34, \mathrm{n}=9$.

\section{Discussion}

In view of the ambient and biological monitoring, it is evident that the workers were exposed both through the lungs and the skin to neat and airborne creosote. Hence, it is important to note that the chemical profiles of liquid creosotes differ from their airborne profiles, a factor complicating exposure assessment for creosote.

Naphthalene is the main component in the air of workplaces where creosote is used, and it reflects well the ambient concentration of the main creosote volatiles to which, notably, pyrene and PAHs do not belong. ${ }^{4}$ This was also evident from our findings indicating that the concentrations of naphthalene vapour were about three orders of magnitude higher, and much more variable, than those of particulate pyrene in personal air samples. Not unexpectedly, the correlation of naphthalene with pyrene in air was non-existent. It is thus evident that 1-HP is not a biomarker for the major volatile fraction of airborne creosote.

Pyrene occurs characteristically with the group of large molecular PAHs, and it is found among the PAHs (chrysene, benzo(k)fluoranthene, benzo(a)pyrene, benzo(ghi)perylene) specifically implicated in the aetiology of human lung cancer. ${ }^{29}{ }^{30} \mathrm{~A}$ methodological difference in the PAH air sampling technique between our study and for example, the study of Tjoe $\mathrm{Ny}$ et $\mathrm{al}^{27}$ is that they used glass fibre filters backed by XAD-2 tubes for quantitative (indoor) trapping of PAHs in a Söderberg potroom of an aluminium smelter. They reported that, in total, $48 \%$ pyrene, $24 \%$ total PAHs, but no benzo(a)pyrene, were found on XAD tubes. Despite these methodological differences, and also the very different types of work environments with widely different airborne concentrations of pyrene ( $\leqslant 100$ times) and benzo(a)pyrene ( $\leqslant 3000$ times), their findings as well as ours support the conclusion that 
there is a strong correlation between pyrene and the total PAHs in the air. In our study, the particulate concentrations of benzo(a)pyrene in air were even at maximum $\left(0.05 \mu \mathrm{g} / \mathrm{m}^{3}\right)$ low compared with its occupational limit value ( 10 $\left.\mu \mathrm{g} / \mathrm{m}^{3}\right),{ }^{31}$ and also low in view of the resultant respiratory doses ( $\leqslant 0.3 \mu \mathrm{g} / 8 \mathrm{~h}$ working day) that were clearly lower than - for example, in a meal high in benzo(a)pyrene (about $5 \mu \mathrm{g}$ ). ${ }^{21}$ Based on the 1-HP urine data, it is evident that the major uptake of carcinogenic PAHs was attributable to creosote exposure through the skin. Although ambient monitoring of benzo(a)pyrene is of indisputable value as a measure of exposure to an actual carcinogen, it was, compared with pyrene, an insensitive PAH marker for the assessment of differences between workers in external exposures to total PAHs in a work environment like the present one.

Although exposure to creosote is typically associated with working outdoors, our findings as well as those of others ${ }^{14} 152532$ point out that the urinary concentrations of 1-HP in creosote workers are very high in comparison with workers exposed to PAHs from other work environments-for example, at a coke plant, ${ }^{163334}$ an aluminium plant, ${ }^{17}$ in asphalt road surfacing, ${ }^{1419}$ and others. ${ }^{35}{ }^{36}$ Also in the light of our own laboratory data, the urinary 1-HP concentrations in creosote workers were very high compared with the controls (mean (SD) $0.27(0.24) \mu \mathrm{mol} / \mathrm{mol}$ creatinine, geometric mean $0 \cdot 20, \mathrm{n}=27$ ) measured in people from urban and rural areas in Estonia.

Zhao et al have shown that the correlations between urinary 1-HP and the ambient concentration of both pyrene $(r=0.987)$ and benzo(a)pyrene $(r=0.959)$ were highly significant in the workers of coke and steel plants, ${ }^{18}$ whereas in our study 1-HP and pyrene did not correlate $(r \leqslant 0 \cdot 34)$.

The daily uptake of inhaled pyrene was far too small to explain the high daily urinary output of 1-HP (table 4). This becomes more evident when it is borne in mind that in humans the urinary $\mathrm{c}$ put of 1-HP may maximally account for $10 \%$ of inhaled pyrene. ${ }^{24}$ After creosote oil was given to rats (4 to 80 $\mathrm{mg} / \mathrm{rat}$, intragastrically) only $5 \%$ to $3 \%$ of the pyrene therein was recovered in 24 hour urine as 1-HP (unpublished own results). In another study on rats the percentage was 10 times lower $(\leqslant 0 \cdot 4 \%) .{ }^{28}$ Hence, the observed lack of relation between 1-HP and inhaled pyrene may best be explained by additional exposure through the skin. The dirtiness of the creosote work was also obvious.

From therapeutic coal tar treatment of patients' skin it is known that pyrene is readily absorbed and excreted at high urinary concentrations of 1-HP. ${ }^{12} 2232$ In view of the study by van Rooij et $a^{25}$ it may be concluded that skin is the main route of PAH uptake in creosote workers.

Our study showed difficulties in selecting appropriate sampling times for biological monitoring of creosote workers. It was evident that the highest concentrations of 1-HP were consistently found in late evening samples but not at the end of the shift, and that the baseline excretion concentration could be determined only after the weekend. Similar conclusions may be drawn from the data presented by van Rooij et al. ${ }^{25}$ Assessment of daily uptake by the net increase of 1-HP in urine as a change within shift has been the common practice in many studies. In our study, however, it was hardly applicable even on Monday. When the workers had been exposed on the day before sampling, this method was not valid at all, because the 1-HP values were mostly higher in the morning than at the end of shift. Hence, the change within shift showed mostly a net decrease (Tuesday to Friday). Also Bos, Jongeneelen, and coworkers ${ }^{15}{ }^{32}$ studied workers who creosoted wood and found that, instead of a net increase, a decrease occurred in urinary 1-HP excretion over the workshifts. Evidently, biomonitoring based on the urine sampling both before and after work may represent rather meaningless sampling times for assessment of exposure to pyrene, especially in workers with apparent skin exposure. Another complicating factor is that in humans the excretion process of 1-HP is biphasic, showing two relatively long half lives: a shorter one (one to two days) for the readily available (for metabolism and then excretion) body pyrene and a longer one (16 days) for the slowly available component. ${ }^{14}$ Both elimination components imply pyrene accumulation, and consistent with this the average net increase in urinary 1-HP over a workday was less than the change within a working week or within the samples taken before shifts (Friday minus Monday values).

The Monday morning concentrations of 1-HP (13 (7) $\mu \mathrm{mol} / \mathrm{mol}$ creatinine) were very high in all the men studied, a finding characteristic for creosote workers. ${ }^{14162532}$ The concentrations were so high that they exceeded not only the upper limits reported for normal 1-HP excretion of unexposed non-smokers 0.66 and smokers $1.3 \mu \mathrm{mol} / \mathrm{mol},{ }^{14}$ but also the biological exposure limits of $2 \cdot 3$ and 4.3 $\mu \mathrm{mol} / \mathrm{mol}$ proposed for coke oven workers ${ }^{37}$ and for workers in a Söderberg potroom, ${ }^{27}$ respectively.

Biotransformation of pyrene into 1-HP by human liver preparations in vitro has shown large differences between people. ${ }^{38}$ It is not clear to what extent differences between people in pyrene biochemistry may cause variation in the urinary excretion rates of 1-HP in general, or in the present workers who reported different intakes of alcoholic beverages and tobacco. Alcohol consumption, medication, and age are known to have little effect on the elimination kinetics of 1-HP in humans. ${ }^{16} 19$ Also the daily amounts of 1-HP excretion that may come from the diet ${ }^{21}$ seem relatively unimportant in creosote workers.

Although smoking is known to increase the 1-HP concentrations in urine, ${ }^{141619}$ it seems to be a negligible source of pyrene exposure in creosote workers. Smoking is thus not a problem to the use of this biomarker. Nevertheless, smoking is a high risk factor in lung cancer; together with occupational 
exposure it may efficiently enhance the pulmonary expression of cytochrome $P-450$ enzymes required for the activation of procarcinogens both in tobacco smoke and in inhaled creosote. ${ }^{39-43}$

Profiles of PAHs such as those of pyrene and known carcinogenic PAHs vary in different work environments. ${ }^{13}$ This is important to know when 1-HP is used to assess exposure to carcinogenic PAHs. For example, the urinary excretion of 1-HP among the creosote workers of our study was almost comparable with the concentrations in the Söderberg potroom workers. $^{27}$ In the potroom workplace, the inhalable concentrations of benzo(a)pyrene were high $\left(<95 \mu \mathrm{g} / \mathrm{m}^{3}\right)$ in contrast with our study where they were low $\left(\leqslant 0.05 \mu \mathrm{g} / \mathrm{m}^{3}\right)$. Knowledge of the PAH profiles, both of the source and the airborne fractions, is thus necessary whenever 1-HP is used as a single biomarker of exposure to total PAHs and for the prediction of cancer risks associated with PAHs in various work environments.

\section{Conclusions}

Ambient concentrations of pyrene were predictive of particulate PAHs but not of naphthalene. The ratio of naphthalene to three to six ring PAHs was two orders of magnitude higher in inspired air than in creosote oil. Naphthalene may thus be used as an ambient marker for those volatiles of creosote that enter the body mainly through the lungs. The urinary excretion of 1-HP was high in all workers, and it showed greater variation between the workers than did the inhaled pyrene. Conspicuous diurnal elimination kinetics showed that the timing of 1-HP sampling is very critical. For the assessment of exposure to pyrene and PAHs 1-HP is a valid biomarker, but not for pyrene if monitored by the ambient method alone, as this ignores the dermal route that in the case of airborne large molecular PAHs seems to be very important. Specific knowledge of the PAH profile in air and creosote oil in the workplace is needed to allow any statement on a worker's actual exposure to carcinogens. In this study, exposure to carcinogenic PAHs through air was low but not necessarily through the skin in view of the results that indicated high dermal uptake of pyrene. Individual measurements of exposures along with hygienic improvements are needed to lower and control dermal exposure in creosote workers.

We are grateful to Dr Matti Romo and the Finnish State Railways, Railways Board, Helsinki, Finland for cooperation and financial support, and to the workers for their contribution. Mrs Tiina Aalto, and Mrs Maria Reinikainen are thanked for excellent technical assistance, Dr Sinikka Vainiotalo for her critical and very helpful comments on the manuscript, and critical and very helpful comments on
Mrs Terttu Kaustia for linguistic revision.

1 Polynuclear aromatic compounds. Bitumens, coal-tars and derived products, shale-oils and soots. LARC Monogr Eval Carcinog Risks Chem Hum 1985;35.

2 Liira J. Creosote. In: Heimburger G, Lundberg P, eds. Criteria documents from Nordic Expert Group 1988. Solna National Institute of Occupational Health, 1988:7-51. (Arbete och Hälsa 33).
3 Overall evaluations of carcinogenicity: an updating of IARC Monographs Vols 1 to 42. LARC Monogr Eval Carcinog Risks Chem Hum 1987; (suppl 7).

4 Nylund L, Heikkilä P, Hämeilä M, Pyy L, Linnainmaa K, Sorsa M. Genotoxic effects and chemical compositions Sorsa M. Genotoxic effects and chemical compo
of four creosotes. Mutat Res 1992;265:223-36.

5 Heikkilä PR, Hämeilä M, Pyy L, Raunu P. Exposure to creosote in the impregnation and handling of impregnated wood. Scand $\mathcal{F}$ Work Environ Health 1987;13: 431-7.

6 Polynuclear aromatic compounds. Chemical, environmental and experimental data. IARC Monogr Eval Carcinog Risks Chem Hum 1983;32.

7 Polynuclear aromatic compounds. Industrial exposure in aluminum production, coal gasification, coke production and iron steel founding. IARC Monogr Eval Carcinog Risks Chem Hum 1984;34.

8 Bertrand JP, Chau N, Patris A, Mur JM, Pham QT, Moulin JJ, et al. Mortality due to respiratory cancers in the cokeoven plants of the Lorraine coalmining industry. the cokeoven plants of the Lorrain
$B r \mathcal{F}$ Ind Med 1987;44:559-65.

9 Verma DK, Julian JA, Roberts RS, Muir DC, Jadon N, Shaw DS. Polycyclic aromatic hydrocarbons (PAHs): a possible cause of lung cancer mortality among possible cause of lung cancer mortality among
nickel/copper smelter and refinery workers. Am Ind Hyg Assoc F 1992;53:317-24.

10 Moulin J, Wild P, Mantout B, Fournier-Betz M, Mur JM, Smagghe G. Mortality from lung cancer and cardiovascular diseases among stainless-steel producing workers. Cancer Causes Control 1993;4:75-81.

11 Karlehagen S, Andersen A, Ohlson C-G. Cancer incidence among creosote-exposed workers. Scand $\mathcal{F}$ Work Environ Health 1992;18:26-9.

12 Jongeneelen FJ, Anzion RBM, Leijdekkers CM, Bos RP, Henderson PTh, Nijenhuis EH, et al. 1-Hydroxypyrene in human urine after exposure to coal tar and coal tar in human urine after exposure to coal tar and coal tar
derived products. Int Arch Occup Environ Health 1985; derived prodi.

13 Jongeneelen FJ, Anzion RBM, Henderson PTh. Determination of hydroxylated metabolites of polycyclic aromatic hydrocarbons in urine. $f$ Chromatogr $A$ 1987; 413:227-32.

14 Jongeneelen FJ, Anzion RBM, Scheepers PTJ, Bos RP, Henderson PTh, Nijenhuis EH, et al. 1-Hydroxypyrene in urine as a biological indicator of exposure to PAH in several work environments. Ann Occup $H y g$ A 1988; 32:35-43.

15 Bos RP, Jongeneelen FJ. Nonselective and selective methods for biological monitoring of exposure to coal-tar products. In: Bartsch H, Hemminki K, O'Neill IK, eds. Methods for detecting DNA damaging agents in humans: applications in cancer epidemiology and prevention. Lyon: applications in cancer epidemiology and prevention.

16 Jongeneelen FJ, Leeuwen FE van, Oosterink S, Anzion RBM, Loop F van der, Bos RP, Veen HG van. Ambient and biological monitoring of cokeoven workers: determinants of the internal dose of polycyclic aromatic hydrocarbons. Brf Ind Med 1990;47:454-61.

17 Tolos WP, Shaw PB, Lowry LK, MacKenzie BA, Deng JF, Markel HL. 1-Pyrenol: a biomarker for occupational exposure to polycyclic aromatic hydrocarbons. Appl Occup Environ Hyg 1990;5:303-9.

$18 \mathrm{Zhao} \mathrm{ZH,} \mathrm{Quan} \mathrm{WY,} \mathrm{Tian} \mathrm{DH.} \mathrm{Urinary} \mathrm{as} \mathrm{an} \mathrm{indicator} \mathrm{of}$ human exposure to ambient polycyclic aromatic hydrocarbons in a coal-burning environment. $S_{c i}$ Total Envirom 1990;92:145-54.

19 Burgaz S, Borm PJA, Jongeneelen FJ. Evaluation of urinary excretion of 1-hydroxypyrene and thioethers in workers exposed to bitumen fumes. Int Arch Occup Workers exposed to bitumen fum

20 Clonfero E, Zordan M, Venier P, Paleologo M, Levis AG, Cottica D, et al. Biological monitoring of human exposure to coal tar. Urinary excretion of total polycyclic aromatic hydrocarbons, and mutagens in psoriatric patients. Int Arch Occup Environ Health 1989;61:363-8.

21 Buckley TJ, Lioy PJ. An examination of the time course from human dietary exposure to polycyclic aromatic hydrocarbons to urinary elimination of 1-hydroxypyrene. $\mathrm{Br} F$ Ind Med 1992;49:113-24.

22 Hansen AM, Poulsen OM, Menne T. Longitudinal study of excretion of metabolites of polycyclic aromatic hydrocarbons in urine from psoriatic patients. Acta Derm Venereol (Stockh) 1993;73:188-90.

23 Van Rooij JGM, Bodelier-Bade MM, De Loof AJA Dijkmans APG, Jongeneelen FJ. Dermal exposure to Dijkmans APG, Jongeneelen FJ. Dermal exposure to
polycyclic aromatic hydrocarbons among primary alupolycyclic aromatic hydrocarbons among prim
minium workers. Med Lav 1992;83:519-29.

24 Van Rooij JGM, Bodelier-Bade MM, Jongeneelen FJ. Estimation of individual dermal and respiratory uptake of polycyclic aromatic hydrocarbons in 12 coke oven workers. Br ₹ Ind Med 1993;50:623-32.

25 Van Rooij JGM, Lieshout EMA van, Bodelier-Bade MM Jongeneelen FJ. Effect of the reduction of skin contamination on the internal dose of creosote workers exposed to polycyclic aromatic hydrocarbons. Scand $\mathcal{F}$ Work Environ Health B 1993;19:200-7.

26 Clark LC, Thompson HL. Determination of creatine and creatinine in urine. Anal Chem 1949;21:1218-21.

27 Tjoe Ny E, Heederik D, Kromhout H, Jongeneelen F. The relationship between polycyclic arornatic hydrocarbons in air and in urine of workers in a Söderberg potroom. Am Ind Hyg Assoc ₹ 1993;54:277-84.

28 Jacob J, Brune H, Gettbarn G, Grimmer D, Heinrich U, Mohtashamipur $\mathrm{E}$, et al. Urinary and faecal excretion of pyrene and hydroxypyrene by rats after oral, 
intraperitoneal, intratracheal or intrapulmonary application. Cancer Lett 1989;46:15-20.

29 Tokiwa H, Sera N, Horikawa K, Nakanishi Y, Shigematu $\mathrm{N}$. The presence of mutagens/carcinogens in the excised lung and analysis of lung cancer induction. Carcinogenesis 1993;14:1933-8.

30 Seto H, Ohkubo T, Kanoh T, Koike M, Nakamura K, Kawahara Y. Determination of polycyclic aromatic hydrocarbons in the lung. Arch Environ Contam Toxicol 1993;24:498-503.

31 National Board of Labour Protection. HTP-arvot 1993. Tampere, Finland: Ministry of Labour, 1993. (Turvallisuustiedote No 25.)

32 Jongeneelen FJ, Bos RP, Henderson PTh. Metabolites of polycyclic aromatic hydrocarbons in urine of exposed polycyclic aromatic hydrocarbons in urine of exposed
workers. Toxicol Environ Chem B 1988;16:295-307.

33 Vähäkangas K, Pyy L, Yrjänheikki E. Assessment of PAHexposure among coke oven workers. Pharmacogenetics 1992;2:304-8

34 Grimmer G, Dettbarn G, Jacob J. Biomonitoring of polycyclic aromatic hydrocarbons in highly exposed coke plant workers by measurement of urinary phenanthrene and pyrene metabolites (phenols and dihydrodiols). Int Arch Occup Environ Health 1993;65:189-99.

35 Granella M, Clonfero E. Urinary excretion of 1-pyrenol in automotive repair workers. Int Arch Occup Environ Health 1993;65:241-5.

36 Van Hummelen P, Gennart JP, Buchet JP, Lauwerys $R$, Kirsch-Volders M. Biological markers in PAH exposed workers and controls. Mutat Res 1993;300:231-9.

37 Jongeneelen FJ. Biological exposure limit for occupational exposure to coal tar pitch volatiles at cokeovens. Int Arch Occup Environ Health 1992;63:511-6.

38 Jongeneelen FJ. Biological monitoring of occupational exposure to polycyclic aromatic hydrocarbons. Nijmegen, The Netherlands: Scientific Publishers, 1987:31-47. (Ph D thesis.)

39 Caporaso N, Hayes RB, Dosemeci M, Hoover R, Ayesh R, Hetzel $M$, Idle J. Lung cancer risk, occupational exposure, and the debrisoquine metabolic phenotype. Cancer Res 1989;49:3675-9.

40 Alexandrov K, Rojas M, Geneste O, Castegnaro M, Camus AM, Petruzzelli S, et al. An improved fluorometric assay for dosimetry of benzo(a)pyrene diol-epoxideDNA adducts in smokers' lung: comparisons with total bulky adduct and arylhydrocarbon hydroxylase activity. Cancer Res 1992;52:6248-53.

41 Sherson D, Sigsgaard T, Overgaard E, Loft S, Poulsen $\mathrm{HE}$, Jongeneelen FJ. Interaction of smoking, uptake of polycyclic aromatic hydrocarbons, and cytochrome P450IA2 activity among foundry workers. $\mathrm{Br} \mathcal{F}$ Ind $\mathrm{Med}$ 1992;49:197-202.

42 Cosma GN, Toniolo P, Currie D, Pasternack BS, Garte SJ. Expression of the CYP1Al gene in periferal lymphocytes as a marker of exposure to creosote in railroad workers. Cancer Epidemiol Biomarkers Prev 1992;1: 137-42.

43 Nakajima T, Elovaara E, Vainio H. Genetic and environmental factors influencing the metabolism of benzo(a) pyrene in human lungs. [abstract.] Parma, Italy: International Symposium on Human Health and Environment, 1994. 